\title{
Antimicrobial Activities of Schiff Base Metal Complexes of First Transition Series
}

\author{
Esmat Laiq ${ }^{1}$ and Nida Shahid ${ }^{2 *}$ \\ ${ }^{1}$ Chemistry Section, Women's College, Department of chemistry, \\ Aligarh Muslim University, Aligarh-202002, India. \\ ${ }^{2}$ Department of chemistry, Arya Mahilla (P.G.) College, \\ Shahjahanpur-242001, India. \\ http://dx.doi.org/10.13005/bbra/2941
}

(Received: 09 August 2021; accepted: 10 September 2021)

\begin{abstract}
The correlative antimicrobial analysis of amino acid Schiff base and derivatized tren metal complexes: $A=\left[\mathrm{MLCl}_{2}\right], B=[\mathrm{ML}(\mathrm{CH} 3 \mathrm{OH}) 2]$, respectively, against fungal strains, Candida parapsilosis, Candida albicans, Candida krusei, and Cryptococcus neoformans and (Gram-negative) P. aeruginosa, E. coli, S. typhimurium, and S. pyogenes, Methicillin-resistant Staphylococcus aureus (MRSA), S. mutans (Gram-positive) bacterial strains had been done by disk diffusion method following McFarland protocol. [CuLCl2] and [Cu $(\mathrm{CH} 3 \mathrm{OH}) 2]$ manifest overwhelming activity against microbes than other metal complexes of cobalt, nickel and zinc. Minimum inhibition concentration data also shows that copper complexes have the lowest MIC values against these tested microorganisms. The significance of this investigation is to uncover shielding and constructive therapeutic agents that wield against bacterial and fungal infection.
\end{abstract}

Keywords: Antibacterial; Disk Diffusion Method; Minimum Inhibitory Concentration (MIC); l-leucine; Schiff base; Thiophene 2-carboxaldehyde.

In coordination chemistry, metal complexes derived from different Schiff base ligands are immanent, and they have played a significant role since the last decades. The derivatives of these ligands are pervasive because they are synthesized very easily and have vast applications. ${ }^{1,2}$. Metal complexes of the Schiff base ligand have expanded extensively due to their meaningful biological, catalytic, and fluorescence activities $^{3,4}$. Schiff bases offer a broad range of biological activities ${ }^{5,6}$ for which the imine or azomethine group existing in their edifices plays a vital role ${ }^{4,7}$ to contribute in bioinorganic sciences; consequently,,, many Schiff base metal complexes are synthesized and assessed for their antifungal and antibacterial activities. The escalating rate of fungal and bacterial strains that ensue resistance to classical antibiotics has reinforced the researchers to develop new antibiotic compounds. Owing to the presence of azomethine $(-\mathrm{C}=\mathrm{N}-)$ functional group, it gets bonded with two or more biologically active heterocyclic or aromatic compounds to form various types of molecular hybrids possessing excellent antimicrobial properties. These Schiff bases are chelating agents that generally coordinate with metals, especially with d-block metals and lanthanides, and form stable chelates with vast therapeutic applications ${ }^{8-10}$. These Schiff bases create a new type of prospective antimicrobial and anticancer reagents ${ }^{11}$. Some Schiff base 
metal complexes, derived from halogenated salicylaldehyde, have enormous applications in a diverse field of study related to luminescent probes, anti-HIV antimicrobial, antitumor, bio-catalysts in DNA and RNA cleavage reactions ${ }^{12}$ due to the excellent coordination with metal ions. These derivatized complexes are also used as fungicides, insecticides, flavoring agents for the bouquet and liquor $^{13,14}$.

In this paper, we report the invitro antifungal and antibacterial activity of Schiff base metal complexes [A] derived from TREN $\left[\mathrm{MLCl}_{2}\right]\left[\mathrm{M}=\mathrm{Co}^{2+}, \mathrm{Ni}^{2+}, \mathrm{Cu}^{2+}, \mathrm{Zn}^{2+}\right]$ and Schiff base metal complex [B] derived from amino acids $\left[\mathrm{ML}\left(\mathrm{CH}_{3} \mathrm{OH}\right)_{2}\right]$. The experimental antimicrobial analysis was performed by using the disk diffusion method ${ }^{15}$. In this method, the antimicrobial impregnated disk is placed on an agar medium previously inoculated with the test microorganism that picks up the moisture, and the antibiotic diffuses radially through the agar medium producing an antibiotic concentration gradient.

\section{MATERIALS AND METHOD}

\section{Chemicals and starting materials}

Analytical grade solvents and reagents were used throughout the experiment. The metal salts $\left(\mathrm{MCl}_{2} \cdot \mathrm{nH}_{2} \mathrm{O}[\mathrm{M}=\right.$ $\left.\left.\mathrm{Co}^{2+}, \mathrm{Ni}^{2+}, \mathrm{Cu}^{2+}, \mathrm{Zn}^{2+}\right]\right) ; \mathrm{CoCl}_{2} \cdot 6 \mathrm{H}_{2} \mathrm{O}, \mathrm{NiCl}_{2} \cdot 6 \mathrm{H}_{2} \mathrm{O}$, $\mathrm{CuCl}_{2} \cdot 2 \mathrm{H}_{2} \mathrm{O}, \mathrm{ZnCl}_{2}$, Merck, Ltd India and the chemicals 1-leucine, glyoxal, Tris (2-amino ethylamine) (TREN), and thiophene 2Carboxaldehyde and organic solvents used were methanol (90\%) and Dimethylsulphoxide (DMSO) fromSigma Aldrich Ltd. De-ionized water was used in all preparations.

\section{Synthesis of Ligands and its complexes [A]} and [B]

Preparation of the Schiff base ligand $\left[\mathrm{L}_{1}\right]$ was done by the condensation of tris (2-amino ethylamine) (TREN) and 2-thiophene carboxaldehyde dissolved in the ethanolic solution with a molar ratio of $1: 3$. The metal complexes A $\left[\mathrm{MLCl}_{2}\right]\left[\mathrm{M}=\mathrm{Co}^{2+}, \mathrm{Ni}^{2+}, \mathrm{Cu}^{2+}, \mathrm{Zn}^{2+}\right]$ were synthesized by direct metallation with the ligand $\left[\mathrm{L}_{1}\right]$ in the ethanolic solution with a molar ratio 1:1. (Scheme.1) The metal complexes [B] $\left[\mathrm{ML}\left(\mathrm{CH}_{3} \mathrm{OH}\right)_{2}\right]$ were prepared according to our last published work [1]. These metal complexes
$\left[\mathrm{M}=\mathrm{Co}^{2+}, \mathrm{Ni}^{2+}, \mathrm{Cu}^{2+}, \mathrm{Zn}^{2+}\right]$ were synthesized from ligand $\left[\mathrm{L}_{2}\right]$ derived from 1-leucine and glyoxal, and the template reaction was carried out in a 1:1:1 ratio. (Scheme 2)

\section{Disk diffusion method}

Disk diffusion method was used for antimicrobial activity of these complexes against bacterial and fungi strains. The microbial inoculums were performed on Brain Heart Infusion (BHI) medium incubated at 37 ! for $18 \mathrm{hrs}$, and Sabouraud Dextrose broth (SDB) medium incubated at 35 ! for $24 \mathrm{hrs}$ for bacterial and fungal strains, respectively and were homogenously distributed onto sterilized petri dishes. The inoculum density of each microorganism was standardized with 0.5 McFarland standards (following McFarland protocol), the suspension had a final inoculum of $10^{5}$ and $10^{6} \mathrm{CFUml}^{-1}$ (colony-forming unit), respectively. Now the saline suspension of $10 \mathrm{iL}$ was mixed with 10 milliters of sterile antimicrobial agar at 40 !. Five Whatman filter paper no. 1 disks of $6.0 \mathrm{~mm}$ diameter were placed on $9 \mathrm{~cm}$ diameter nutrient agar (NA) plates. Then the microorganisms were individually loaded on the surface of the disks. A blank disk was soaked in the solvent (DMSO) and entrenched as a negative control with no inhibitory region on each plate along with the standard drugs. These testing complexes diffuse into the agar and inhibit the growth and germination of the test microorganism, and then the diameters of inhibition growth zones that emerged around the samples disk were measured in millimeters.

\section{In Vitro-Antimicrobial activity}

In order to analyze the antibacterial activity, the stock solution was prepared by dissolving $1 \mathrm{mg}$ of the test metal complex in 100il of DMSO. From this stock solution, various concentrations such as 10.0,20.0, 25.0,50.0, and $100.00 \mathrm{microgram} / \mathrm{microliters}$ of the complexes were prepared. Different concentration of test compound was poured on the disk plate. Disks of DMSO were treated as a $-\mathrm{ve}$ control and that of chloramphenicol as a +ve control against the gramnegative and gram-positive bacterial strains.

For the antifungal activities, incubation of inoculums of Cryptococcus neoformans, Candida parapsilosis, Candida albicans, and Candida krusei were done for 24 hours at 35! in Sabouraud Dextrose broth. The sterile saline solution was used to prepare the suspension of about $10^{6} \mathrm{CFUml}^{-1}$ by 
following Macfarland Protocol (The turbidity of the suspension was adjusted to a McFarland standard of 0.5 . For the stock solution preparation, $1 \mathrm{mg}$ of the metal complexes dissolved in 100.0 microliters of DMSO. From the stock solution, various concentrations such as 10.0,20.0, 25.0, 50.0, 100.0 microgram / microliters of the complexes were prepared. Different concentration of test compound was poured on the diskplate. Disks of DMSO were utilized as a negative control and that of fluconazole as the positive control. The sensitivity of various fungal strains against both the complex ligands $\left[\mathrm{MLCl}_{2}\right]$ and $\left[\mathrm{ML}\left(\mathrm{CH}_{3} \mathrm{OH}\right)_{2}\right]$ was evaluated depending on the diameter of the inhibition zone against fungal strains after forty-eight hours of incubation at temperature of 35 !.

First of all, complexes [A] and [B] were dissolved in DMSO, and then aliquots of these complexes were prepared at various concentrations, i.e., 512.0, 256.0, 128.0, 64.0, $32.0,16.0,8.0,4.0,2.0,1.0 \mathrm{milligram} / \mathrm{milliliter}$. To calculate MIC, broth micro dilution was performed in sterile 96-well micro plates in which microbes under study are inoculated into a medium with different concentrations of metal complexes A and B. Growth of the microorganism is evaluated after 20 hours of incubation at 37 ! ,MIC value is read.

Table 1. Zone of inhibition ( $\mathrm{mm}$ ) of $\left[\mathrm{MLCl}_{2}\right]$ with chloramphenicol antibiotic against Gram +ve and Gram - ve bacterial strains

\begin{tabular}{lcccccc}
\hline Complexes & S.mutans & $\begin{array}{c}\text { Gram }+\mathrm{ve} \\
\text { S.pyogenes }\end{array}$ & MRSA** & E.coli & $\begin{array}{c}\text { Gram -ve } \\
\text { P.aeruginosa }\end{array}$ & S.typhimurium \\
\hline$\left[\mathrm{CoLCl}_{2}\right]$ & $10.9 \pm 0.5$ & $14.1 \pm 0.4$ & $17.1 \pm 0.3$ & $16.5 \pm 0.2$ & $15.0 \pm 0.2$ & $19.1 \pm 0.2$ \\
{$\left[\mathrm{NiLCl}_{2}\right]$} & $11.5 \pm 0.4$ & $15.5 \pm 0.4$ & $12.8 \pm 0.5$ & $13.2 \pm 0.2$ & $11.8 \pm 0.1$ & $10.1 \pm 0.8$ \\
{$\left[\mathrm{CuLCl}_{2}\right]$} & $25 \pm 0.3$ & $21.7 \pm 0.3$ & $20.8 \pm 0.4$ & $19.3 \pm 0.2$ & $15.4 \pm 0.2$ & $23.01 \pm 0.5$ \\
{$\left[\mathrm{ZnLCl}_{2}\right]$} & $10.2 \pm 0.3$ & $9.5 \pm 0.2$ & $14.8 \pm 0.4$ & $11.3 \pm 0.2$ & $10.6 \pm 0.3$ & $15.7 \pm 0.4$ \\
$\mathrm{Chloramp}^{*}$ & $27.1 \pm 0.5$ & $22.5 \pm 0.4$ & $21 \pm 0.5$ & $20.6 \pm 0.3$ & $18.0 \pm 0.2$ & $25.5 \pm 0.6$ \\
DMSO & - & - & - & - & - & - \\
\hline
\end{tabular}

*Chloramphenicol, **Methicillin-resistant Staphylococcus aureus

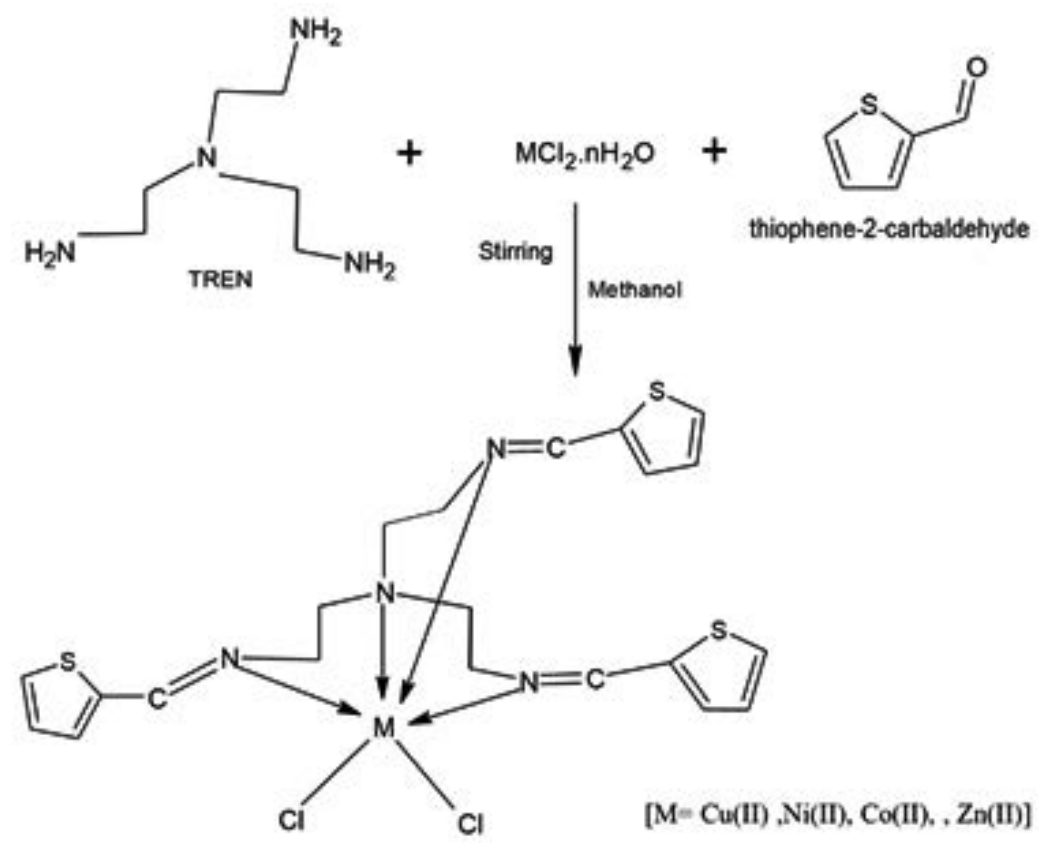

Scheme 1. Synthesis and proposed structure of complexes[A] 
RESULTS AND DISCUSSION

All the metal complexes reveal antimicrobial activity, and they were found to be active inhibitors against bacterial strains. (Table1, 2) and fungal strains (Table 3, 4). Responsiveness of both the testing coordinated complexes $\mathrm{A}=$ $\left[\mathrm{MLCl}_{2}\right]$ and $\mathrm{B}=\left[\mathrm{ML}\left(\mathrm{CH}_{3} \mathrm{OH}\right)_{2}\right]\left(\mathrm{M}=\mathrm{Co}^{2+}, \mathrm{Ni}^{2+}\right.$, $\mathrm{Cu}^{2+}, \mathrm{Zn}^{2+}$ ) was evaluated based on the diameter of the inhibition zone against Pseudomonas aeruginosa, Escherichia coli, Salmonella typhimurium, (Gram-negative) and Streptococcus pyogenes, Methicillin-resistant Staphylococcus aureus (MRSA), Streptococcus mutans (Grampositive) bacterial strains. The analysis of results presented in Tables 1 and 2 shows the antibacterial activities of four different metal-ligand complexes against the gram-negative and gram-

Table 2. Zone of inhibition ( $\mathrm{mm})$ of $\left[\mathrm{ML}\left(\mathrm{CH}_{3} \mathrm{OH}\right)_{2}\right]$ with Chloramphenicol antibiotic against Gram +ve and Gram -ve bacterial strains

\begin{tabular}{lcccccc}
\hline Complexes & \multicolumn{3}{c}{ Gram $+\mathrm{ve}$} & \multicolumn{3}{c}{ Gram -ve } \\
& S.mutans & S.pyogenes & MRSA** & E.coli & P.aeruginosa & S.typhimurium \\
\hline$\left[\mathrm{CoL}\left(\mathrm{CH}_{3} \mathrm{OH}\right)_{2}\right]$ & $11.9 \pm 0.6$ & $15.1 \pm 0.3$ & $18.1 \pm 0.2$ & $16 \pm 0.3$ & $12.0 \pm 0.2$ & $18.3 \pm 0.4$ \\
{$\left[\mathrm{NiL}\left(\mathrm{CH}_{3} \mathrm{OH}\right)_{2}\right]$} & $12.5 \pm 0.5$ & $11 \pm 0.5$ & $9 \pm 0.4$ & $14.4 \pm 0.8$ & $11.0 \pm 0$ & $16.1 \pm 0.8$ \\
{$\left[\mathrm{CuL}\left(\mathrm{CH}_{3} \mathrm{OH}\right)_{2}\right]$} & $23 \pm 0.5$ & $21 \pm 0.2$ & $20.5 \pm 0.5$ & $18.3 \pm 0.3$ & $16.5 \pm 0.2$ & $22.2 \pm 0.4$ \\
{$\left[\mathrm{ZnL}\left(\mathrm{CH}_{3} \mathrm{OH}\right)_{2}\right]$} & $12.1 \pm 0.2$ & $10.5 \pm 0.5$ & $15.0 \pm 0.6$ & $12.3 \pm 0.5$ & $11.2 \pm 0.4$ & $17.4 \pm 0.2$ \\
Chloramp* & $27.1 \pm 0.5$ & $22.5 \pm 0.4$ & $21 \pm 0.5$ & $20.6 \pm 0.3$ & $18.0 \pm 0.2$ & $25.5 \pm 0.6$ \\
DMSO & - & - & - & - & - & - \\
\hline
\end{tabular}

*Chloramphenicol, **Methicillin-resistant Staphylococcus aureus<smiles>CC(C)CC(N)C(=O)O</smiles>

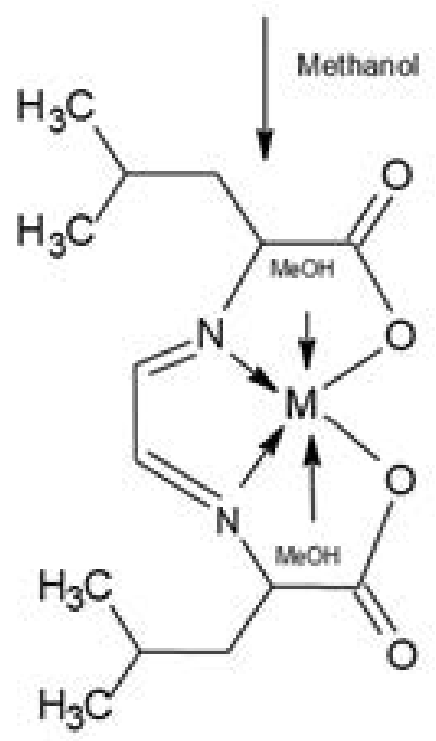

Scheme 2. Synthesized structure of Schiff base complexes[B] (Prepared earlier by Shakiret al [1]) 
positive bacterial strains. In vitro screening for all coordinated complexes was performed at different concentrations mentioned above, and the results were compared with chloramphenicol antibiotic. The values of the diameter of inhibition zone of $\left[\mathrm{CuLCl}_{2}\right]$ and $\left[\mathrm{CuL}\left(\mathrm{CH}_{3} \mathrm{OH}\right)_{2}\right]$ complexes show that these antimicrobial agents are effective in controlling the growth of all the bacterial strains studied when compared with the positive (chloramphenicol), and negative (DMSO) controls.

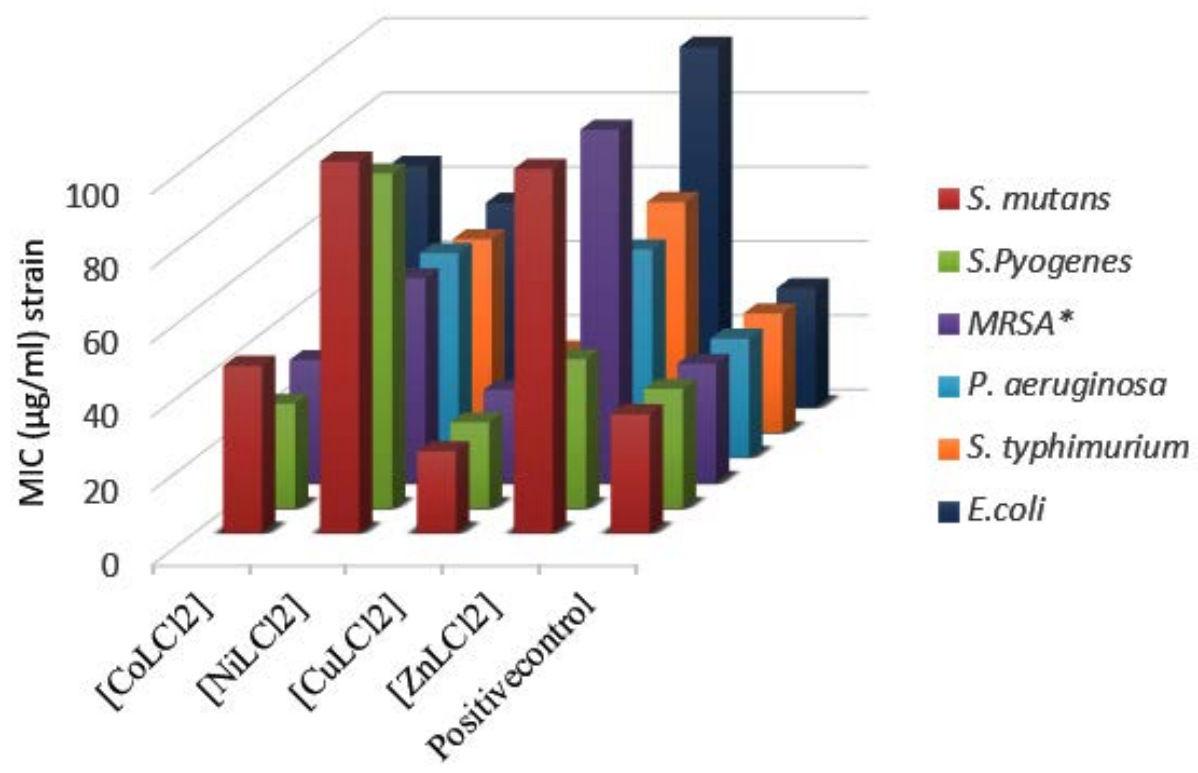

Fig. 1. MIC of $\left[\mathrm{MLCl}_{2}\right]$ complexes positive control chloramphenicol

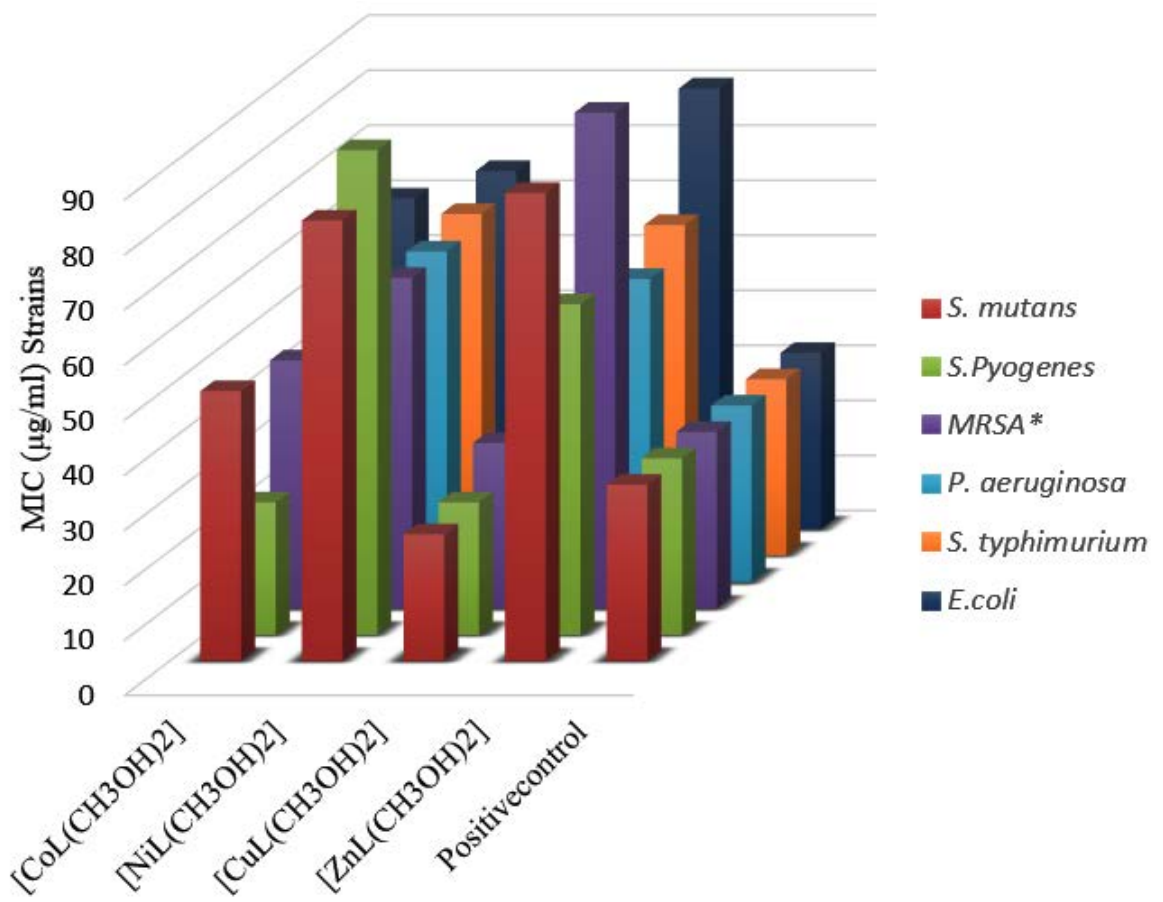

Fig. 2. $\mathrm{MIC}$ of $\left[\mathrm{ML}\left(\mathrm{CH}_{3} \mathrm{OH}\right)_{2}\right]$ complexes positive control chloramphenicol 
In addition, cobalt complexes and nickel complexes were also effective against $P$. aeruginosa, $E$. coli, S. typhimurium, MRSA, and S. pyogenes, $S$. mutants, respectively. The results also point out that the $\left[\mathrm{ZnLCl}_{2}\right]$ complexes are less active than other complexes. Data are indexed in Tables 1 and 2.

Compared to the standard antifungal drug fluconazole, all the metal chelates exhibited antifungal activity against C. albicans $C$. krusei, C. neoformans, and C. parapsilosis. Among all testing complexes, $\left[\mathrm{CuLCl}_{2}\right]$ and $\left[\mathrm{CuL}\left(\mathrm{CH}_{3} \mathrm{OH}\right)_{2}\right]$ complexes were most active against the fungal strains and showed the highest activity against $C$. krusei (i.e., $19.0 \pm 1.2$ and $18.5 \pm 1.3$ respectively). The activity is greatly enhanced at higher concentrations. DMSO (-ve control) has shown

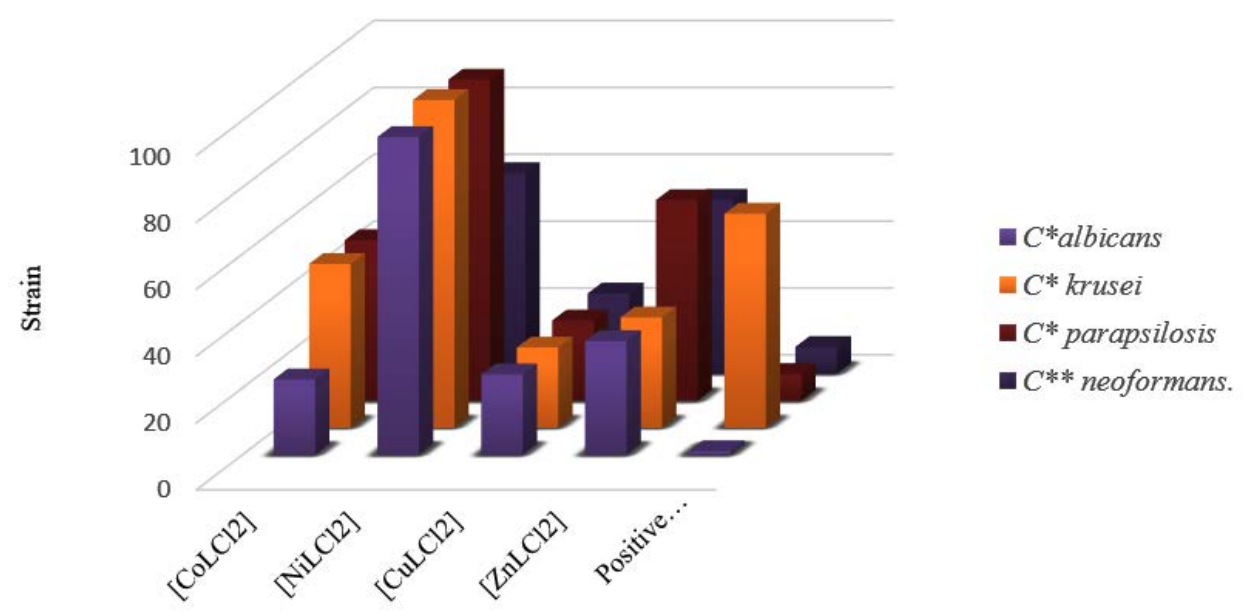

Fig. 3. $\mathrm{MIC}$ of $\left[\mathrm{MLCl}_{2}\right]$ positive control Fluconazole

Table 3. Antifungal Activity of $\left[\mathrm{MLCl}_{2}\right]+$ ve control(Fluconazole), and -ve control (DMSO) measured by the Halo Zone Test (mm)

\begin{tabular}{lcccc}
\hline \multirow{2}{*}{ Complexes } & \multicolumn{4}{c}{ Effect on microorganism } \\
& C. albicans & C. krusei & C.parapsilosis & C. neoformans. \\
\hline$\left[\mathrm{CoLCl}_{2}\right]$ & $13.4 \pm 0.3$ & $12.2 \pm 1.2$ & $12 \pm 0.5$ & $11.5 \pm 0.2$ \\
{$\left[\mathrm{NiLCl}_{2}\right]$} & $12.5 \pm 0.1$ & $14.6 \pm 0.2$ & $9.9 \pm 1.2$ & $9.5 \pm 0.4$ \\
{$\left[\mathrm{CuLCl}_{2}\right]$} & $18.8 \pm 0.5$ & $19.0 \pm 1.2$ & $16.9 \pm 0.2$ & $15.6 \pm 0.3$ \\
{$\left[\mathrm{ZnLCl}_{2}\right]$} & $12.1 \pm 0.3$ & $14.5 \pm 0.4$ & $13.2 \pm 0.6$ & $11.1 \pm 0.4$ \\
Fluconazole & $20 \pm 0.5$ & $20 \pm 0.5$ & $18 \pm 0.5$ & $19 \pm 0.5$ \\
DMSO & - & - & - & - \\
\hline
\end{tabular}

Table 4. Antifungal Activity of $\left[\mathrm{ML}\left(\mathrm{CH}_{3} \mathrm{OH}\right)_{2}\right]+$ ve control(Fluconazole), and -ve control (DMSO) measured by the Halo Zone Test (mm)

\begin{tabular}{lcccc}
\hline \multirow{2}{*}{ Complexes } & \multicolumn{3}{c}{ Effect on microorganism } \\
& C.albicans & C. krusei & C.parapsilosis & C. neoformans. \\
\hline$\left[\mathrm{CoL}\left(\mathrm{CH}_{3} \mathrm{OH}\right)_{2}\right]$ & $14.5 \pm 0.5$ & $15.1 \pm 1.4$ & $11.8 \pm 0.5$ & $10.5 \pm 0.1$ \\
{$\left[\mathrm{NiL}\left(\mathrm{CH}_{3} \mathrm{OH}\right)_{2}\right]$} & $11.5 \pm 0.2$ & $12.6 \pm 0.2$ & $10 \pm 1.3$ & $9.8 \pm 0.5$ \\
{$\left[\mathrm{CuL}\left(\mathrm{CH}_{3} \mathrm{OH}\right)_{2}\right]$} & $19.0 \pm 0.5$ & $18.5 \pm 1.3$ & $17.1 \pm 0.1$ & $16.8 \pm 0.4$ \\
{$\left[\mathrm{ZnL}\left(\mathrm{CH}_{3} \mathrm{OH}\right)_{2}\right]$} & $15.1 \pm 0.5$ & $16.5 \pm 0.1$ & $15.0 \pm 0.8$ & $12.1 \pm 0.6$ \\
Fluconazole & $20 \pm 0.5$ & $20 \pm 0.5$ & $18 \pm 0.5$ & $19 \pm 0.5$ \\
DMSO & - & - & - & - \\
\hline
\end{tabular}




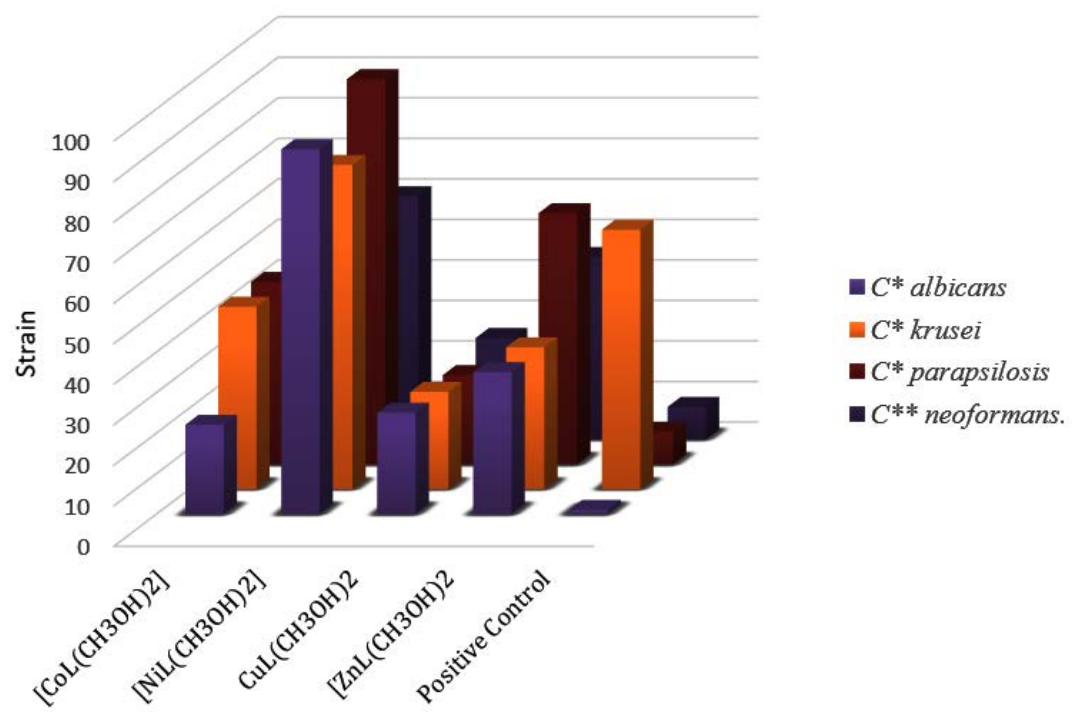

Fig. 4. $\mathrm{MIC}$ of $\left[\mathrm{ML}\left(\mathrm{CH}_{3} \mathrm{OH}\right)_{2}\right]$ positive control Fluconazole

negligible activity as compared to these chelates. Antifungal activity data reveals that the activity of complexes depends upon the type of metal ion present in the complex, and it is observed that $\left[\mathrm{CuLCl}_{2}\right]$ and $\left[\mathrm{CuL}\left(\mathrm{CH}_{3} \mathrm{OH}\right)_{2}\right]$ complex are the most dynamic and complexes $\left[\mathrm{NiLCl}_{2}\right]$ and $\left[\mathrm{NiL}\left(\mathrm{CH}_{3} \mathrm{OH}\right)_{2}\right]$ are least active, whereas complexes $\left[\mathrm{CoLCl}_{2}\right],\left[\mathrm{CoL}\left(\mathrm{CH}_{3} \mathrm{OH}\right)_{2}\right]$ and $\left[\mathrm{ZnLCl}_{2}\right],\left[\mathrm{ZnL}\left(\mathrm{CH}_{3} \mathrm{OH}\right)_{2}\right]$ are active against the fungal strains. Data are given in Tables 3,4.

The minimum inhibitory concentration (MIC) was the lowest concentration of antimicrobial agent at which there is no visible growth and development of the tested microorganism after incubation $^{16}$. The antibacterial and antifungal screening concentrations of Schiff base compounds were deduced from the minimum inhibitory concentration value. The MIC values of the compounds (figures 1-4) revealed that $\left[\mathrm{CuLCl}_{2}\right]$ and $\left[\mathrm{CuL}\left(\mathrm{CH}_{3} \mathrm{OH}\right)_{2}\right]$ had a minimum inhibition value than cobalt complexes $\left[\mathrm{CoLCl}_{2}\right],\left[\mathrm{CoL}\left(\mathrm{CH}_{3} \mathrm{OH}\right)_{2}\right]$ whereas nickel and zinc complexes showed highest MIC values. From these MIC values data (shown in figures 1-4), it was found that fewer amount of copper complexes will be required for inhibiting the growth of the organism and can act as a conspicuous antimicrobial agent.

Complexes of copper exhibit analogously more inhibition compared to antibiotics used. MIC data in figures 1, 2, 3 and 4 show that copper complexes have proved to be the most active against the microbes tested at the concentrations used. The high antibacterial and antifungal activity of the copper complexes can be explained by the fact that the process of normal cells gets affected due to the copper ions. Therefore, the polarity of such metal ions decreases because the partial +ve charge on these metal ions attached with the donor groups of the ligands delocalizes the electrons over the entire chelating ring during the complexation reaction ${ }^{17}$; as a result, the central metal atom shows increased lipophilic character due to which it infiltrates with high affinity in the microorganisms via a lipid layer of the cell membrane.

\section{CONCLUSION}

Schiff base ligands are privileged ligands because they are prepared by a simple condensation of primary amines and aldehydic derivatives. These metal-based Schiff base chelates have significant biological properties for modification towards future drug development as microorganisms invalidate current antimicrobial agents effectiveness through many adaptations and resistance.

In our study these $\left[\mathrm{CuLCl}_{2}\right]$ and $\left[\mathrm{CuL}\left(\mathrm{CH}_{3} \mathrm{OH}\right)_{2}\right]$ complexes showed enhanced activity than compared with these $\left[\mathrm{MLCl}_{2}\right]$ and $\left[\mathrm{ML}\left(\mathrm{CH}_{3} \mathrm{OH}\right)_{2}\right]\left[\mathrm{M}=\mathrm{Co}^{2+}, \mathrm{Ni}^{2+}, \mathrm{Zn}^{2+}\right]$ complexes. 
The apparent distinction of antibacterial and antifungal activities of these derivatized compounds verifies the purpose of this research work. Generally, copper coordination complexes, due to highly effective redox activity and the biogenicity of its ions, show numerous biological activities and are also very effective in treating fungal and bacterial infections [18-20]. The practical significance shows that such a compound may be more efficient against these microbes, for which a detailed analysis about their biological effects, toxicity can be more effective in devising antibacterial and antifungal agents for therapeutic use. Therefore, these new antimicrobial agents should efficiently possess a different mode of action to combat resistance in pathogenic species.

\section{ACKNOWLEDGEMENT}

The authors are thankful to Chairman, Department of Chemistry, Aligarh Muslim University, Aligarh, for providing research facilities.

\section{Conflict of Interest} declared.

There is no conflict of interest to be

\section{Funding Source}

There is no funding or financial support for this research work.

\section{REFERENCES}

1. Shakir M, Shahid N, Sami N, Azam M, and Khan A. U. Synthesis, spectroscopic characterization and comparative DNA binding studies of Schiff base complexes derived from 1-leucine and glyoxal.SpectrochimicaActa - Part A: Molecular and Biomolecular Spectro., 2011;82(1): 31-36. https://doi.org/10.1016/J.SAA.2011.06.035

2. Abdel-Rahman L. H, Abu-Dief A. M, Aboelez M. O, and Hassan Abdel-Mawgoud A. A. DNA interaction, antimicrobial, anticancer activities and molecular docking study of some new $\mathrm{VO}(\mathrm{II}), \mathrm{Cr}(\mathrm{III}), \mathrm{Mn}(\mathrm{II})$ and Ni(II) mononuclear chelates encompassing quaridentate imine ligand. Journal of Photochemistry and Photobiology B: Biology, 2017; 170: 271-285. https:/doi. org/10.1016/J.JPHOTOBIOL.2017.04.003

3. Akhmetova V. R, Khabibullina G. R, Galimzyanova N. F, and Ibragimov A. G. One-pot synthesis and fungicidal activity of 2-(1,5,3-dithiazepan-3-yl)ethanol and N,N2 -bis(2-hydroxyethyl)tetrathiadiazacycloalkanes. Russ. J. of App. Chem., 2014; 87(3): 294-298. https://doi.org/10.1134/S1070427214030082

4. Arslan H, Duran N, Borekci G, Ozer C. $\mathrm{K}$, andAkbay C. Antimicrobial Activity of Some Thiourea Derivatives and Their Nickel and Copper Complexes, Molecules, 2009; 14(1): 519-527.https://doi.org/10.3390/ MOLECULES14010519

5. Barnabas M.J, Parambadath S, Nagappan S, Chung I and Ha C.S. Silver (I)-Schiff-base complex intercalated layered double hydroxide with antimicrobial activity. Adv. Nano Res., 2021; 10(4):373-383. doi:10.12989/anr.2021.10.4.373

6. Chikisheva G. E, SapozhnikovYu. E, Mudarisova R. Kh, Buslaeva L. I, Galieva Z. B, and Davletov R. D. Synthesis and fungicidal activity of 2-benzoylaminobenzimidazole complex compounds with copper. Russian J. of Appl. Chem., 2013; 86(2): 285-288. https://doi. org/10.1134/S107042721302262

7. Fekri R, Salehi M,Asadi A andKubicki M. Synthesis, characterization, anticancer and antibacterial evaluation of Schiff base ligands derived from hydrazone and their transition metal complexes. Inorg. Chimica Acta., 2019; 484:245254. https://doi.org/10.1016/J.ICA.2018.09.022

8. Fonkui Y.T, Ikhile I. M,Ndinteh T. D and Njobeh B P. Microbial activity of some heterocyclic Schiff bases and metal complexes: A review. Trop. J. of Pharm. Research, 2018; 17(12): 25072518 http://dx.doi.org/10.4314/tjpr.v17i12.29

9. Mahmoud H. W, Deghadi G. R and Mohamed G. G. Metal complexes of ferrocenyl-substituted Schiff base: Preparation, characterization, molecular structure, molecular docking studies, and biological investigation. Journal of Organometallic Chemistry, 2020; 917:121113 https://doi.org/10.1016/j. jorganchem.2020.121113

10. Phan D.N, Dorjjugder N, Khan M. Q, Saito Y, Taguchi G, Lee H, Mukai Y and Kim I-S. Synthesis and attachment of silver and copper nanoparticles on cellulose nanofibers and comparative antibacterial study. Cellulose, 2019; 26: 6629-6640. https://doi.org/10.1007/s10570019-02542-6

11. Heatley N. G. A method for the assay of penicillin. Biochemical Journal, 1944; 38(1): 61-65https://doi.org/10.1042/BJ0380061

12. Ibraev M. K, KozhinaZh. M, Gazaliev A. M, and Fazylov S. D. Synthesis and biological activity of ethyl [N-(alkylthio)thiocarbonyl] aminoacetates. Russian Journal of Applied Chemistry, 2006; 79(2): 329-330. https://doi. org/10.1134/S1070427206020339 
13. Liu X, and Hamon J. R. Recent developments in penta-, hexa- and heptadentate Schiff base ligands and their metal complexes. Coordination Chemistry Reviews, 2019; 389: 94-118. https:// doi.org/10.1016/J.CCR.2019.03.010

14. Sharma D, Revanasiddappa H.D and Jayalakshmi B. DNA/BSA interaction and in vitro antimicrobial studies of $\mathrm{Mn}$ (III) complexes bearing bidentate N, O donor Schiff bases. J. Iran Chem. Soc., 2020; 17(1):43-58. doi:10.1007/ s13738-019-01745-9

15. Utreja D, VibhaB. S. P, Singh S, and Kaur M. Schiff Bases and their Metal Complexes as AntiCancer Agents:A Review. Current Bioactive Compounds, 2015;11(4): 215-230. https://doi. org/10.2174/1573407212666151214221219

16. Hols P, García L.L, Gabant, J and Mignolet P. Mobilization of Microbiota Commensals and Their Bacteriocins for Therapeutics, Trends Microbiol., 2019; 27(8):690-702 https://doi. org/10.1016/j.tim.2019.03.007
17. Zhao X, Song D. K, Radbil' A. B, and Radbil' B. A. Synthesis and biological activity of Schiff bases derived from dehydroabietylamine and benzaldehyde derivatives. Russ. J.of Applied Chemistry, 2007; 80(8):1373-1375. https://doi. org/10.1134/S1070427207080216

18. Krasnovskaya O, Naumov A, Guk D, Gorelkin P, Erofeev A, Beloglazkina E and Majouga A. Copper Coordination Compounds as Biologically Active Agents. Int. J. Mol. Sci., 2020; 21: 3965. doi:10.3390/ijms21113965

19. Iakovidis I, Delimaris I and Piperakis M. S. Copper and Its Complexes in Medicine: A Biochemical Approach. Molecular Biology International, 2011. https://doi.org/10.4061/2011/594529

20. Gaál, A.; Orgován, G, Mihucz, V.G, Pape, I, Ingerle, D, Streli, C and Szoboszlai, N.J. Metal Transport Capabilities of Anticancer Copper Chelators. Trace Elem. Med. Biol., 2018; 47: 79-88. DOI: 10.1016/j.jtemb.2018.01.011 